\title{
PELATIHAN KOMUNIKASI EFEKTIF UNTUK MENGURANGI SHYNESS PADA MAHASISWA BARU PENDATANG DI MAKASSAR
}

\author{
Mariyani Husen ${ }^{1}$, Widyastuti ${ }^{2}$, Hilwa Anwar ${ }^{3}$ \\ ${ }^{1,2,3}$ Fakultas Psikologi, Universitas Negeri Makassar \\ Email: mariyani_husen@yahoo.co.id ${ }^{1}$,widyastuti@unm.ac.id ${ }^{2}$ \\ hilwa.anwar@unm.ac.id ${ }^{3}$
}

\begin{abstract}
Abstrak. Penelitian ini bertujuan untuk mengetahui perbedaan tingkat shyness mahasiswa pendatang yang mengikuti pelatihan dengan mahasiswa pendatang yang tidak mengikuti pelatihan komunikasi efektif di Makassar. Subjek dalam penelitian ini adalah sebanyak 32 orang mahasiswa yang terpilih melalui metode purposive sampling. Subjek dibagi menjadi dua kelompok yaitu 18 orang pada kelompok eksperimen dan 14 orang pada kelompok kontrol. Subjek pada kelompok eksperimen diberikan pelatihan komunikasi efektif sedangkan subjek pada kelompok kontrol tidak diberikan pelatihan. Alat pengumpulan data yang digunakan dalam penelitian ini adalah skala shyness. Desain penelitian yang digunakan adalah randomized pretestposttest control group design. Hasil penelitian menunjukkan bahwa tingkat shyness pada subjek yang diberikan pelatihan komunikasi efektif mengalami penurunan dibandingkan dengan subjek yang tidak mendapatkan pelatihan. Hal tersebut terlihat dari hasil analisis data dengan menggunakan uji t melalui program SPSS 16.0, nilai $t$ sebesar 5,690 ( $p=0,000)$. Berdasarkan hasil analisis tersebut, dapat disimpulkan bahwa pelatihan komunikasi efektif untuk mengurangi shyness pada mahasiswa pendatang di Makassar.
\end{abstract}

Kata Kunci: komunikasi efektif. mahasiswa baru, shyness

\begin{abstract}
This study aims to determine differences in the level of shyness of new students who attend training with new students who do not attend effective communication training in Makassar. Subjects in this study were 32 students selected through the purposive sampling method. Subjects were divided into two groups: 18 people in the experimental group and 14 people in the control group. Subjects in the experimental group were given effective communication training while subjects in the control group were not given training. Data collection tools used in this study are shyness scale. The research design used was randomized pretest-posttest control group design. The results showed that the level of shyness in subjects given effective communication training decreased compared to subjects who did not receive training. This can be seen from the results of data analysis using the t test through the SPSS 16.0 program, $t$ value of $5.690(p=0,000)$. Based on the results of the analysis, it can be concluded that communication communication is effective in reducing shyness to new students in Makassar.
\end{abstract}

Keywords: effective communication, new student, working mother. 


\section{PENDAHULUAN}

Manusia merupakan makhluk sosial yang berhubungan dan berinteraksi dengan manusia lainnya untuk menjalani kehidupan. Sejak lahir, individu memiliki kebutuhan-kebutuhan yang diwujudkan dengan bantuan orang lain (Gerungan, 2004). Pemenuhan kebutuhan-kebutuhan tersebut akan mendorong seseorang untuk melakukan interaksi dengan orang lain, baik dalam bekerjasama maupun untuk melakukan persaingan (Azenismail, 2010). Namun, akan menjadi masalah jika individu tersebut mengalami rasa malu yang berlebihan dan memiliki kendala dalam melakukan interaksi sosial.

Setiap manusia memiliki rasa malu (shyness), baik pada anak-anak maupun orang dewasa. Ridfah, Daud, \& Murdiana (2007) mengemukakan bahwa shyness yang dimiliki tiap individu berada dalam taraf kewajaran tertentu, namun jika shyness berada dalam taraf berlebihan dapat menghambat potensi diri yang ingin dikembangkan individu tersebut. Buss (BAŞ, 2010) mengemukakan bahwa shyness didefinisikan sebagai ketidaknyamanan, hambatan, dan kecanggungan dalam situasi sosial, terutama dalam berinteraksi dengan orang asing.

Shyness merupakan suatu kondisi kegelisahan, tidak menyenangkan, dan terhambat yang disebabkan oleh kehadiran orang lain (Chaplin, 2006). Chung dan Evans (Ridfah, Daud, \& Murdiana, 2007) menjelaskan bahwa shyness merupakan istilah yang dipakai untuk menjelaskan ketidaknyamanan individu berada dalam suatu situasi yang membuat individu tersebut menarik diri dari situasi tersebut. Hal tersebut senada dengan yang dikemukakan Henderson, Zimbardo, dan Carducci (1999) yang mendefinisikan shyness sebagai pengalaman akan ketidaknyamanan atau hambatan dalam situasi antarpribadi yang mengganggu seseorang dalam mencapai tujuan. Henderson dan Zimbardo (tanpa tahun) menyebutkan ada empat gejala shyness yang terdiri dari perilaku, fisiologis, kognitif, dan afektif yang kemudian dijadikan aspek-aspek dari shyness.

Maswan (2001) mengemukakan bahwa penyebab individu mengalami shyness karena kecerdasan sosial yang rendah. Hal tersebut mengakibatkan individu yang mengalami shyness cenderung tidak memiliki keterampilan berkomunikasi, seperti memperkenalkan diri, memulai suatu percakapan, serta keterampilan menunjukkan bahasa tubuh. Keterampilan berkomunikasi tersebut diperoleh dari proses belajar individu yang berasal dari faktor lingkungan.

Henderson dan Zimbardo (tanpa tahun) mengemukakan bahwa faktor yang menyebabkan shyness yaitu ketika berada dalam situasi interpersonal. Hal tersebut senada dengan yang dikemukakan oleh BAŞ (2010) bahwa shyness timbul pada saat individu berada di lingkungan baru dan dikelilingi oleh orang asing. Individu yang mengalami shyness tinggi akan berusaha menghindari interaksi dengan orang asing tersebut.

Individu yang mengalami shyness tinggi cenderung lebih memilih berdiam diri saat berada dalam suatu kegiatan. Penelitian yang dilakukan Coplan, Prakash, O'Neil, dan Armer (Xu, Farver, Yang, \& Zeng, 2008) menjelaskan bahwa pada dasarnya individu yang mengalami shyness tinggi termotivasi untuk terlibat dalam interaksi bersama teman sebayanya, tetapi terhalangi oleh kecemasan ketika memulai interaksi. 
Individu kemudian cenderung menampilkan pola perilaku sebagai penonton yang hanya melihat teman sebayanya berinteraksi.

Penelitian lain yang dilakukan oleh Rubin dan Asendorpf (Xu, dkk., 2008) di Amerika Utara menunjukkan bahwa individu yang mengalami shyness tinggi dan pendiam cenderung bermasalah pada penyesuaian diri dengan lingkungannya. Anggarasari dan Kumolohadi (2007) mengemukakan bahwa individu yang mengalami shyness tinggi cenderung menghindari interaksi sosial dan pasif, ketakutan, bicara dengan suara pelan, sulit mengekspresikan diri, bicara tidak lancar, dan cemas. Ciri-ciri tersebut bertentangan dengan tuntutan individu sebagai mahasiswa.

Mahasiswa sebagai calon intelektual atau cendekiawan muda dalam suatu lapisan masyarakat diharapkan mampu menjadi pemimpin (Rahmawati, dalam Senjaya, 2010). Namun, akan menjadi masalah apabila mahasiswa tersebut tidak mampu bersosialiasi dengan lingkungan. Hasil penelitian yang dilakukan Ridfah, Daud, dan Murdiana (2007) menyebutkan bahwa sekitar 98\% mahasiswa di kota Makassar mengalami shyness. Kecenderungan shyness yang dialami mahasiswa dapat mengganggu proses pendidikan dan kehidupan sosial mahasiswa tersebut. Hal yang paling sering membuat mahasiswa shyness yaitu ketika berbicara di depan umum, mengemukakan pendapat saat berdiskusi, berada dalam masalah, berbicara dengan individu yang memiliki kekuasaan, dan penampilan yang kurang menarik. Hal tersebut dapat berdampak pada penilaian mahasiswa di kelas, karena salah satu penilaian dosen terhadap mahasiswa adalah termasuk aktif di kelas, baik mengenai kehadiran mahasiswa tersebut di kelas maupun aktif mengemukakan pendapat, dan berkontribusi pada saat berdiskusi.

Penelitian yang dilakukan Mohamed dan Hamzah (2005) pada 140 mahasiswa Melayu mengenai hubungan shyness dengan prestasi akademik yang terdiri dari 56 mahasiswa tahun kedua, 79 mahasiswa tahun ketiga, dan lima mahasiswa tahun keempat. Hasil penelitian tersebut menunjukkan bahwa ada hubungan negatif antara shyness dengan prestasi akademik di kalangan mahasiswa Melayu. Shyness yang dialami mahasiswa tersebut dapat menyebabkan mahasiswa tidak aktif di kelas, terjadi kejenuhan belajar, motivasi belajar rendah, sehingga dapat mempengaruhi prestasi akademik menjadi rendah.

Agus (Manurung, 2008) mengemukakan bahwa menurut keberadaannya mahasiswa dapat dibedakan menjadi dua, yaitu mahasiswa asli dan mahasiswa pendatang. Mahasiswa asli adalah mahasiswa yang lahir, tumbuh dan berkembang di tempat yang sama dimana mahasiswa tersebut melanjutkan pendidikan. Ciri-ciri utama mahasiswa asli yaitu tinggal bersama orang tua. Mahasiswa pendatang adalah mahasiswa yang lahir, tumbuh dan berkembang di tempat atau daerah yang berbeda dengan tempat mahasiswa tersebut melanjutkan pendidikan. Ciri-ciri utama dari mahasiswa pendatang yaitu tinggal di rumah kontrakan dan seringkali tidak didampingi oleh orang tua.

Lei (2003) melakukan penelitian pada siswa pendatang yang berasal dari Asia Tenggara yang berdomisili di Amerika. Hasil penelitian tersebut menunjukkan bahwa siswa yang berasal dari Asia Tenggara mengalami shyness ketika berada dalam lingkungan sekolah maupun di dalam kelas. Hal tersebut disebabkan oleh kondisi 
yang asing dan anggapan bahwa dialek siswa Asia Tenggara akan ditertawakan oleh siswa Amerika.

Mc Croskey (Anggarasari \& Kumolohadi, 2007) mengemukakan bahwa faktorfaktor yang menyebabkan individu mengalami shyness adalah kondisi yang asing, situasi formal, perhatian sosial yang berlebihan atau tidak, dan privacy terganggu. Kondisi yang asing dan perhatian sosial yang berlebihan atau tidak mendapatkan perhatian merupakan suatu kondisi yang dialami oleh mahasiswa pendatang. Hal tersebut yang menyebabkan mahasiswa pendatang memiliki shyness tinggi jika dibandingkan dengan mahasiswa asli.

Shyness juga dapat menimbulkan kesepian pada mahasiswa pendatang. Sears, Freedman, dan Peplau (1999) mengemukakan bahwa mahasiswa pendatang pada semester awal sering mengalami ketegangan ketika perpisahan dengan teman dan keluarga, serta kecemasan mengenai kehidupan sosial yang baru yang mengakibatkan mahasiswa tersebut merasakan kesepian. Dill dan Anderson (BAŞ, 2010) menambahkan bahwa shyness merupakan awal mula seseorang merasakan kesepian dan beberapa variabel yang berkontribusi dengan kesepian sering dialami oleh individu yang mengalami shyness. Pada awalnya ketakutan dan kecemasan dapat mengganggu upaya individu untuk berinteraksi dengan orang lain. Kegagalan interaksi sosial yang dialami individu tersebut akan menyebabkan individu mengalami shyness sehingga menghindari pertemuan-pertemuan sosial. Jackson, Fritch, Nagasaka, dan Gunderson (BAŞ, 2010) mengemukakan bahwa ketika individu tersebut memiliki kontak sosial lebih sedikit dari yang diinginkan, maka individu akan merasakan kesepian.

Bem, Caspi, dan Elder (Myers, 2005) mengemukakan bahwa individu yang mengalami shyness cenderung tidak terlibat dalam interaksi sosial dan mengasingkan diri dari orang lain. Myers (2005) menambahkan bahwa individu mengalami shyness dikarenakan tidak memiliki keterampilan sosial seperti keterampilan dalam berkomunikasi, diakibatkan kecerdasan sosial yang rendah. Oleh karena itu, individu yang tidak memiliki keterampilan komunikasi sering menghindari situasi interpersonal.

Mangkuprawira (2008) mengemukakan bahwa kebanyakan dari individu yang memiliki kecerdasan sosial yang rendah tidak mengetahui seni memperkenalkan diri, memulai suatu percakapan, dan tidak menguasai keterampilan komunikasi nonverbal. Dengan kata lain, individu yang mengalami shyness tinggi kurang mengetahui bagaimana tata cara berinteraksi dengan orang lain secara efektif. Sehingga pengetahuan tentang komunikasi efektif dalam berinteraksi dengan orang lain sangat diperlukan pada individu yang mengalami shyness tinggi.

Supratiknya (1995) mengemukakan bahwa komunikasi dikatakan efektif jika penerima menginterpretasikan pesan yang diterima sebagaimana dimaksudkan oleh pengirim dan juga seberapa jauh akibat-akibat dari tingkah laku individu sesuai dengan tujuan yang ingin dicapai. Apabila komunikasi yang terjadi dapat berlangsung efektif, maka individu dapat memahami maksud dari orang lain sebagai lawan bicara. Begitupun sebaliknya, individu dapat menyampaikan maksud yang dikehendaki kepada orang lain dengan baik dan masing-masing menghasilkan tindakan yang diharapkan. 
Keterampilan berkomunikasi dapat dimiliki tiap individu dengan cara melatih diri dalam berkomunikasi dengan orang lain. Supratiknya (Gunawati, Hartati, \& Listiara, 2006) menambahkan bahwa komunikasi dapat membantu individu dalam proses perkembangan intelektual dan sosial, pembentukan identitas diri dan jati diri, sumber pembanding sosial dan penentu kesehatan mental. Komunikasi juga sangat penting untuk membina hubungan dengan orang lain, karena dengan komunikasi individu dapat memperoleh informasi atau wacana baru untuk mengembangkan potensi yang ada dalam dirinya.

Berdasarkan penjelasan yang telah dipaparkan sebelumnya maka dapat disimpulkan bahwa shyness yang dialami mahasiswa pendatang dapat mengganggu proses pendidikan dan kehidupan sosialnya. Hal tersebut dikarenakan mahasiswa pendatang kurang memahami keterampilan dalam berkomunikasi. Keterampilan berkomunikasi dapat dilatih dan dimiliki tiap individu dengan memberikan pemahaman mengenai komunikasi efektif. Hal tersebut dapat membantu mahasiswa belajar untuk mengeksplorasi hal-hal positif dalam diri, dapat mengekspresikan perasaan, berani mengemukakan pendapat, dan dapat berbagi pengalaman, sehingga dengan pelatihan komunikasi efektif diharapkan mahasiswa pendatang dapat mulai nyaman dan terampil dalam berkomunikasi dan dapat mengurangi shyness yang berlebihan.

Hipotesis dalam penelitian ini adalah ada perbedaan tingkat shyness mahasiswa pendatang yang mengikuti pelatihan dengan mahasiswa pendatang yang tidak mengikuti pelatihan komunikasi efektif di Makassar. Tingkat shyness mahasiswa pendatang yang mengikuti pelatihan menurun dibandingkan dengan mahasiswa yang tidak mengikuti pelatihan.

\section{METODE}

Penelitian ini menggunakan pendekatan kuantitatif eksperimental. Desain eksperimen yang digunakan dalam penelitian yaitu randomized pretest-posttest control group design. Shadish, Cook, dan Campbell (2002) menjelaskan bahwa rancangan eksperimen ini digunakan untuk mengukur efektivitas suatu perlakuan untuk jangka waktu tertentu, baik sebelum maupun sesudah perlakuan tersebut diberikan. Subjek dalam penelitian ini dibagi ke dalam dua kelompok, yakni kelompok eksperimen yang dikenai variabel perlakuan X (Pelatihan Komunikasi Efektif) dan kelompok kontrol tidak diberikan perlakuan. Kedua kelompok subjek tersebut diberikan pre-test dan post-test yang digunakan dalam penelitian ini

Teknik sampling yang digunakan adalah purposive sampling. Pemilihan subjek dilakukan menggunakan teknik purposive sampling, dimana pemilihan sampel sesuai dengan pertimbangan tertentu (Sugiyono, 2011). Jika subjek sesuai dengan kriteria yang diinginkan, maka subjek tersebut akan dilibatkan dalam penelitian ini. Kriteria subjek dalam penelitian ini, yaitu: 1) Subjek merupakan mahasiswa pendatang yang berasal dari luar Makassar, karena mahasiswa pendatang merupakan mahasiswa yang lahir, tumbuh dan berkembang di daerah yang berbeda dengan tempat mahasiswa tersebut melanjutkan pendidikan. 2) Tidak tinggal dengan keluarga, karena salah satu penyebab shyness adalah individu berada pada lingkungan yang asing dan lebih dituntut untuk dapat berinteraksi dengan lingkungan tersebut. 3) Mahasiswa semester I. Mahasiswa semester awal mengalami ketegangan dalam menyesuaikan diri dengan 
lingkungan yang baru dan dikhawatirkan masalah tersebut akan berlanjut pada semester-semester berikutnya. 4) Mahasiswa yang memiliki skor skala shyness tinggi. Penentuan subjek dilakukan dalam dua tahap, yaitu:

1. Tahap penjaringan subjek

Tahap penjaringan subjek dilakukan dengan memberikan skala pengukuran shyness kepada mahasiswa baru yang sesuai dengan kriteria subjek di Universitas Hasanuddin, Universitas Negeri Makassar, dan UIN Alauddin Makassar. Skala pengukuran shyness yang disebar sebanyak 300, namun yang berhasil terkumpulkan sebanyak 247 lembar dengan kelengkapan data subjek. Berdasarkan hasil kategorisasi berdasarkan distribusi normal dengan kategorisasi jenjang (Azwar, 2010), disajikan sebagai berikut:

Tabel 1.Hasil deskriptif kategorisasi subjek penelitian

\begin{tabular}{cccc}
\hline Interval & Frekuensi & Persentase & Kategori \\
\hline $\mathrm{X} \geq 138$ & 36 & $14,58 \%$ & Tinggi \\
\hline $95 \leq \mathrm{X}<138$ & 171 & $69,23 \%$ & Sedang \\
\hline $\mathrm{X}<95$ & 40 & $16,19 \%$ & Rendah \\
\hline Total & 247 & $100 \%$ &
\end{tabular}

Selanjutnya, dari 247 mahasiswa yang mengisi skala shyness, hanya 36 orang yang memiliki skor shyness tinggi.

2. Tahap penentuan subjek

Berdasarkan tahap penjaringan subjek ditemukan 36 orang yang memiliki skor shyness tinggi, yang kemudian di random ke dalam kelompok eksperimen dan kelompok kontrol berdasarkan random assignment. Hal tersebut berarti setiap subjek memiliki kesempatan yang sama untuk ditempatkan di setiap kondisi perlakuan dan kesediaan subjek untuk mengikuti rangkaian penelitian (Sugiyono, 2011). Proses randomisasi diharapkan dapat diperoleh dua kelompok subjek yang relatif homogen.

Teknik random dilakukan dengan metode undian. Prosedur randomisasi yang dilakukan yaitu peneliti menyususun nama-nama subjek yang memenuhi kriteria sebayak 36 orang dan diminta kesediaannya untuk dilibatkan dalam penelitian. Selanjutnya peneliti mengundi nama-nama tersebut untuk dimasukkan ke dalam dua kelompok. Subjek kelompok eksperimen berjumlah 18 orang selanjutnya akan diberikan pelatihan komunikasi efektif dan subjek kelompok kontrol berjumlah 18 orang tidak mendapatkan perlakuan. Akan tetapi pada saat pemberian post-test, 4 orang dari kelompok kontrol tidak dapat dihubungi sehingga kelompok kontrol berjumlah 14 orang.

Manipulasi variabel independen yang dimaksud adalah langkah-langkah atau prosedur eksperimen berlangsung. Subjek yang telah melalui proses penyaringan di bagi ke dalam dua kelompok, yaitu kelompok eksperimen dan kelompok kontrol. Kelompok yang mendapatkan perlakuan (pelatihan komunikasi efektif) yaitu kelompok eksperimen, sedangkan kelompok control tidak mendapatkan perlakuan. Proses pemberian perlakuan pada kelompok eksperimen, antara lain: 
1. Materi pertama yang diberikan pada pelatihan tersebut adalah konsep diri. Trainer memberikan penjelasan dan pemahaman mengenai makna dari konsep diri, perbedaan konsep diri positif dan negatif, hingga menumbuhkan rasa percaya diri pada peserta pelatihan. Sebelumnya trainer memutarkan video dan meminta peserta mengikuti gerakan yang ada dalam video tersebut dengan tujuan menumbuhkan keberanian pada peserta untuk percaya diri.

2. Materi kedua merupakan materi hubungan interpersonal, dimana shyness tercipta pada saat situasi interpersonal. Materi yang diberikan merupakan penjelasan dan pemahaman bagaimana cara membangun hubungan yang baik dengan orang lain. Setelah pemberian materi, dilanjutkan dengan games pedekate yang merupakan permainan yang berkaitan dengan hubungan interpersonal. Tujuan dari games tersebut yaitu melatih peserta untuk percaya, membuka diri terhadap orang lain dan memiliki sikap suportif.

3. Materi ketiga yaitu komunikasi verbal. Isi dari materi tersebut yaitu makna, bentuk-bentuk, aspek-aspek, dan cara meningkatkan keterampilan komunikasi verbal. Selanjutnya, akan diberikan games yang berkaitan dengan materi tersebut yaitu komunikata. Games tersebut dimaksudkan agar peserta dapat langsung mempraktekkan dan mengerti maksud dari materi tersebut. Penguasaan kata-kata sangat diperlukan dalam berkomunikasi dengan orang lain agar tercipta komunikasi efektif.

4. Materi keempat yaitu materi komunikasi nonverbal. Isi dari materi tersebut yaitu makna dan bentuk-bentuk komunikasi nonverbal, bahasa tubuh dan gerakan mata, serta ditutup dengan games tebak gaya. Games yang diberikan pada setiap akhir materi dimaksudkan agar peserta mengetahui maksud dan tujuan dari materi tersebut.

5. Sesi terakhir dari pelatihan ini adalah teknik relaksasi dengan tujuan sebagai penguatan untuk peserta agar dapat diaplikasikan dalam kehidupan sehari-hari.

Setelah pelatihan dilaksanakan, peserta diberikan lembar evaluasi kesesuaian materi dengan trainer. Satu minggu kemudian peserta diberikan lembar evaluasi pembelajaran, apakah materi yang diberikan dapat membantu peserta pelatihan dalam kehidupan sehari-hari. Evaluasi terakhir atau post-test diberikan sebulan kemudian setelah proses pelatihan berlangsung dengan tujuan untuk melihat apakah terjadi perubahan sikap atau tidak

Data dalam penelitian dikumpulkan menggunakan skala shyness. Skala shyness diberikan kepada subjek penelitian untuk menyeleksi subjek yang berada pada kategori shyness tinggi sebelum (pretest) dan setelah (posttest) pelaksanaan pelatihan komunikasi efektif. Skala ini dirancang oleh Ridfah (2012) berdasarkan pada aspekaspek yang dikemukakan oleh Henderson dan Zimbardo (tanpa tahun). Berdasarkan uji coba ulang terhadap alat ukur ini, diperoleh hasil sebagai berikut: 1) Daya diskriminasi item dari 52 item yang di uji coba terdapat 45 item yang dapat digunakan dan memiliki daya diskriminasi item yang bergerak antara $0,257-0,636 ; 2$ ) Reliabilitas alpha yang diperoleh dari alat ukur ini adalah 0,926.

Pengukuran pengetahuan subjek penelitian menggunakan lembar evaluasi pemahaman merupakan kuesioner yang mengungkap pengetahuan dan pengalaman individu tentang komunikasi efektif. Lembar evaluasi atau kuesioner ini berisi pertanyaan-pertanyaan tertutup yang disusun berdasarkan materi-materi dalam modul 
pelatihan. Kuesioner ini dibagikan sebelum dan sesudah materi diberikan kepada subjek yang mengikuti pelatihan. Pengukuran efektivitas pelatihan menggunakan lembar evaluasi reaktif dan lembar evaluasi pembelajaran. Lembar evaluasi reaktif berisi tentang pertanyaan dan kesan subjek mengenai kesesuaian materi dan trainer. Lembar evaluasi ini dibagikan setelah penutupan pelatihan komunikasi efektif. Lembar evaluasi pembelajaran berisi tentang pernyataan-pernyataan mengenai pengetahuan dan keterampilan yang didapatkan setelah mengikuti pelatihan komunikasi efektif. Lembar evaluasi ini diberikan satu minggu setelah pelatihan dengan tujuan untuk mengetahui apakah materi yang diberikan berpengaruh dalam kehidupan sehari-hari atau tidak.

Teknik analisis data yang digunakan dalam penelitian ini menggunakan analisis analisis uji t-independen dengan bantuan SPSS.

\section{HASIL}

Sebanyak 18 orang mahasiswa yang dipilih secara acak untuk mengikuti pelatihan yang merupakan kelompok eksperimen, sedangkan 14 orang lainnya merupakan kelompok kontrol yang tidak mengikuti pelatihan.

a. Gambaran rerata hipotetik dan rerata empirik kelompok eksperimen

Nilai respon dari skala shyness berurut dari yang paling rendah yakni 1 hingga yang paling tinggi yakni 5, dengan jumlah aitem sebanyak 45 aitem. Kemungkinan skor shyness terendah pada sampel penelitian yakni 45 dan skor shyness tertinggi pada sampel penelitian yakni 225. Mean hipotetik sebesar 135 dengan standar deviasi (SD) sebesar 30.

Hasil penelitian menunjukkan bahwa skor terendah pre-test skala shyness adalah 138 dan skor tertinggi skala shyness sebesar 187 dengan rerata empirik sebesar 154,11 dan standar deviasi (SD) sebesar 14,919. Skor terendah post-test skala shyness adalah 100 dan skor tertinggi skala shyness sebesar 158 dengan rerata empirik sebesar 136,89 dan standar deviasi (SD) sebesar 14,891. Berikut ini adalah gambaran perbandingan rerata hipotetik dan rerata empirik dari hasil skala shyness pada kelompok eksperimen dapat dilihat pada tabel berikut:

Tabel 2. Perbandingan rerata hipotetik dan rerata empirik kelompok eksperimen

\begin{tabular}{ccccccccc} 
Variabel & \multicolumn{3}{c}{ Rerata Hipotetik } & \multicolumn{5}{c}{ Rerata Empirik } \\
\cline { 2 - 8 } & Max & Min & Mean & SD & Max & Min & Mean & SD \\
\hline $\begin{array}{c}\text { Shyness } \\
\text { Pre-test }\end{array}$ & 225 & 45 & 135 & 30 & 187 & 138 & 154,11 & 14,919 \\
\hline $\begin{array}{c}\text { Shyness } \\
\text { Post-test }\end{array}$ & 225 & 45 & 135 & 30 & 158 & 100 & 136,89 & 14,891 \\
\hline
\end{tabular}

b. Gambaran rerata hipotetik dan rerata empirik kelompok kontrol

Nilai respon dari skala shyness berurut dari yang paling rendah yakni 1 hingga yang paling tinggi yakni 5, dengan jumlah aitem sebanyak 45 aitem. Kemungkinan skor shyness terendah pada sampel penelitian yakni 45 dan skor shyness tertinggi pada sampel penelitian yakni 225. Mean hipotetik sebesar 135 dengan standar deviasi (SD) sebesar 30. 
Hasil penelitian menunjukkan bahwa skor terendah pre-test skala shyness adalah 138 dan skor tertinggi skala shyness sebesar 179 dengan rerata empirik sebesar 154,79 dan standar deviasi (SD) sebesar 13,279. Skor terendah post-test skala shyness adalah 148 dan skor tertinggi skala shyness sebesar 189 dengan rerata empirik sebesar 165,07 dan standar deviasi (SD) sebesar 11,000. Berikut ini adalah gambaran perbandingan rerata hipotetik dan rerata empirik dari hasil skala shyness pada kelompok kontrol dapat dilihat pada tabel berikut:

Tabel 3. Perbandingan rerata hipotetik dan rerata empirik kelompok control

\begin{tabular}{lcccccccc}
\hline & \multicolumn{3}{c}{ Rerata Hipotetik } & & \multicolumn{3}{c}{ Rerata Empirik } \\
\cline { 2 - 8 } Variabel & Max & Min & Mean & SD & Max & Min & Mean & SD \\
\hline $\begin{array}{l}\text { Shyness } \\
\text { Pre-test }\end{array}$ & 225 & 45 & 135 & 30 & 179 & 138 & 154,79 & 13,279 \\
\hline $\begin{array}{l}\text { Shyness } \\
\text { Post-test }\end{array}$ & 225 & 45 & 135 & 30 & 189 & 148 & 165,07 & 11,000 \\
\hline
\end{tabular}

Berdasarkan hasil analisis deskriptif tersebut, dapat dilihat pada tabel rerata empirik dan rerata hipotetik pada kelompok eksperimen dan kelompok kontrol. Hasil analisis menunjukkan pada kelompok eksperimen terdapat penurunan mean empirik sebelum dan setelah pelatihan dilaksanakan, nilai mean empirik sebelum pelatihan sebesar 154,11 dan mean empirik setelah pelatihan sebesar 136,89. Hasil analisis kelompok kontrol menunjukkan terdapat peningkatan mean empirik pre-test dan post-test, dimana mean empirik pre-test sebesar 154,79 dan mean empirik post-test sebesar 165,07. Hal tersebut menunjukkan bahwa terjadi penurunan skor tingkat shyness setelah mengikuti pelatihan komunikasi efektif.

\section{Hasil uji hipotesis}

Hipotesis dalam penelitian ini adalah ada perbedaan tingkat shyness mahasiswa pendatang yang mengikuti pelatihan dengan mahasiswa pendatang yang tidak mengikuti pelatihan komunikasi efektif di Makassar. Uji hipotesis dalam penelitian ini menggunakan teknik analisis uji t independen (independent sample t test). Seniati, Yulianto, dan Setiadi (2009) mengemukakan bahwa sesuai dengan desain eksperimen randomized pretest-posttest control group design, skor yang dijadikan perhitungan dalam independent sample t-test adalah gain score, yaitu selisih antara skor pre-test dan post-test.

Tabel 4. Hasil Independet samples T-test

\begin{tabular}{lccccc}
\hline Variabel & Levene's Test $(p)$ & $t$ & $d f$ & $P$ & Mean difference \\
\hline Shyness & .150 & -5.690 & 30 & .000 & -27.508 \\
\hline
\end{tabular}

Berdasarkan hasil analisis statistik dengan uji t (Independent Samples T-test) dengan bantuan SPSS seri 16.0 menunjukkan bahwa nilai Levene's Test tidak signifikan karena $(p)=0,150>0,05$, yang artinya varian dalam kedua kelompok adalah sama. Oleh karena itu, nilai $t$ yang dilihat yaitu nilai $t$ pada kolom pertama yaitu $t=-5,690$ dengan signifikansi $(P=0,000)$. Hal tersebut menunjukkan bahwa nilai 
$t$ signifikan, dimana $(P)=0,000<0,05$ yang berarti hipotesis diterima. Hasil uji $\mathrm{t}$ menunjukkan bahwa tingkat shyness mahasiswa pendatang di Makassar yang mengikuti pelatihan dengan mahasiswa pendatang yang tidak mengikuti pelatihan komunikasi efektif berbeda, dimana tingkat shyness mahasiswa pendatang yang mengikuti pelatihan mengalami penurunan dibandingkan dengan mahasiswa yang tidak mengikuti pelatihan. (Data uji hipotesis terlampir).

\section{Evaluasi pelatihan}

a. Evaluasi pengetahuan

Evaluasi pengetahuan merupakan evaluasi yang disusun untuk mengukur tingkat pengetahuan peserta pelatihan mengenai komunikasi efektif. Pertanyaan-pertanyaan yang terdapat dalam lembar evaluasi pengetahuan ini disusun berdasarkan materimateri dalam modul pelatihan sebanyak 10 soal. Lembar evaluasi diberikan sebelum dan setelah materi pelatihan diberikan. Nilai yang diperoleh peserta pelatihan sebelum mendapatkan materi terlihat lebih kecil jika dibandingkan dengan jumlah nilai setelah mendapatkan materi pelatihan. Hal tersebut menunjukkan bahwa dengan pelatihan komunikasi efektif mampu menambah pengetahuan subjek tentang komunikasi efektif.

b. Evaluasi reaktif

Evaluasi reaktif merupakan pengukuran yang berisi tentang pertanyaan dan kesan subjek mengenai kesesuaian materi dan trainer. Lembar evaluasi tersebut dibagikan setelah penutupan pelatihan komunikasi efektif. Evaluasi reaktif ini dimaksudkan untuk melihat kesesuaian antara materi dan trainer yang langsung dinilai oleh peserta pelatihan sebagai bentuk evaluasi efektivitas pelatihan yang dilaksanakan. Berdasarkan lembar evaluasi materi dan trainer, skor terendah dalam evaluasi reaktif ini yaitu Tidak Setuju (TS) diberi nilai 1 dan skor tertinggi yaitu Sangat Setuju (SS) diberi nilai 3. Diketahui standar rata-rata skor yang diperoleh dari ketentuan skor 1 sampai 3 terhadap materi dan trainer yaitu 1,5 yang menunjukkan bahwa materi pelatihan yang diberikan dinilai telah sesuai dan kemampuan trainer dalam memberikan materi dinilai baik oleh peserta. Secara keseluruhan evaluasi reaktif memiliki rata-rata skor jawaban peserta terhadap materi dan trainer yaitu 2,33 yang berarti kesesuaian materi dan cara penyampaian serta metode yang digunakan oleh trainer dinilai memuaskan.

c. Evaluasi pembelajaran

Hatta (2011) mengemukakan bahwa evaluasi materi terhadap peningkatan soft skill merupakan bentuk evaluasi yang disusun berdasarkan tujuan-tujuan yang ingin dicapai. Evaluasi pembelajaran yang dimaksudkan dalam penelitian ini yaitu melihat apakah materi yang diberikan memiliki kontribusi dalam peningkatan soft skill peserta pelatihan terhadap masalah yang dialaminya. Evaluasi pembelajaran menunjukkan hasil positif.

\section{DISKUSI}

Hipotesis dalam penelitian ini adalah ada perbedaan tingkat shyness mahasiswa pendatang yang mengikuti pelatihan komunikasi efektif dengan mahasiswa pendatang yang tidak mengikuti pelatihan komunikasi efektif. Hipotesis tersebut dibuktikan dengan prosedur eksperimen untuk melihat efektivitas pelatihan komunikasi efektif 
terhadap penurunan shyness dengan membandingkan sko $\mathrm{r}$ shyness sebelum dan setelah pelatihan pada kelompok eksperimen, serta membanding skor kelompok eksperimen dan skor kelompok kontrol menggunakan uji t. Hasil analisis statistik dengan uji t menunjukkan bahwa $t=-5,690$ dengan signifikansi $(p)=0,000$, dimana kaidah jika $p<0,005$ yang berarti hipotesis diterima. Berdasarkan hasil analisis tersebut, pelatihan komunikasi efektif berpengaruh terhadap penurunan shyness. Subjek pada kelompok eksperimen memiliki tingkat shyness yang lebih rendah dibandingkan dengan subjek pada kelompok kontrol.

Hasil penelitian tersebut sesuai dengan hasil penelitian sebelumnya yang dilakukan oleh Myers (2005) dimana terdapat hubungan negatif antara keterampilan komunikasi dengan shyness. Penelitian yang dilakukan pada 63 mahasiswa yang menunjukkan bahwa individu yang mengalami shyness tinggi dikarenakan kurangnya keterampilan dalam berkomunikasi. Oleh karena itu, sesuai dengan hasil penelitian yang dilakukan oleh peneliti bahwa pelatihan komunikasi efektif dapat menurunkan tingkatan shyness. Hasil penelitian ini sejalan dengan yang dikemukakan oleh Nufandi (2000) bahwa dengan mempelajari aturan dan tata cara berperilaku sosial sangat membantu individu untuk mengatasi shyness yang berlebihan.

Berdasarkan hasil analisis deskriptif diperoleh bahwa gambaran secara umum mengenai skala shyness sebelum diadakan perlakuan (pre-test), subjek yang tergolong tingkatan shyness tinggi yaitu 32 orang. Sebanyak 18 subjek yang merupakan kelompok eksperimen nantinya diberikan perlakuan (Pelatihan Komunikasi Efektif), sedangkan 14 orang lainnya merupakan kelompok kontrol tidak diberikan perlakuan. Hasil penelitian menunjukkan bahwa terjadi penurunan rerata empirik pada kelompok eksperimen dimana mean pada pre-test 154,11 dan setelah diberikan perlakuan mean post-test sebesar 136,89. Berbeda halnya dengan kelompok kontrol yang mengalami kenaikan rerata empirik, dimana mean pre-test 154,79 sedangakan mean post-test sebesar 165,07. Hasil tersebut memberikan gambaran subjek yang mengikuti pelatihan komunikasi efektif mengalami penurunan tingkatan shyness setelah diadakan pelatihan, sedangkan subjek yang tidak mengikuti pelatihan tidak mengalami penurunan tingkatan shyness.

Hasil penelitian ini didukung oleh hasil penelitian yang dilakukan oleh Anggarasari dan Kumolohadi (2007) menemukan bahwa ada pengaruh pelatihan komunikasi interpersonal terhadap rasa malu pada mahasiswa di Jogjakarta. Subjek yang mengikuti pelatihan bertindak sebagai kelompok eksperimen mengalami perubahan yang lebih baik, jika dibandingkan subjek pada kelompok kontrol yang tidak mengikuti pelatihan. Meskipun hasil penelitian tersebut menunjukkan pelatihan tersebut efektif untuk menurunkan shyness yang dialami oleh seseorang, akan tetapi ada baiknya individu yang mengalami shyness perlu mengikuti terapi secara berkala.

Berdasarkan hasil evaluasi pembelajaran yang diberikan kepada subjek penelitian kelompok eksperimen, sebanyak 72,22\% menganggap keseluruhan materi sangat diperlukan untuk mengatasi masalah yang dialaminya. Respon peserta terhadap materi yang dianggap penting yaitu konsep diri dengan respon terbanyak yaitu sebesar 50\%. Materi konsep diri juga merupakan materi yang perlu dikembangkan, dimana respon peserta terhadap materi tersebut dengan persentase terbanyak yaitu $44,44 \%$. 
Sejalan dengan yang dikemukakan oleh Nufandi (2000) bahwa modal utama dalam mengatasi shyness yaitu memiliki kepercayaan yang kuat terhadap diri sendiri. Keyakinan terhadap diri sendiri bergantung pada seberapa kuat perasaan individu tentang kelebihan yang dimiliki individu tersebut. Salah satu alasan peserta menganggap materi konsep diri merupakan materi yang perlu dikembangkan dan dianggap penting, karena individu dapat membangun konsep diri positif dan segala hal yang dilakukan akan berjalan dengan baik tanpa ada keraguan dan perasaan takut atau kurang percaya diri.

Hasil penelitian lain yang ditemukan oleh Schein (Tubbs \& Moss, tanpa tahun) bahwa kemampuan untuk meningkatkan manfaat komunikasi antarpribadi merupakan keahlian yang istimewa. Manfaat tersebut tidak hanya untuk pengembangan pribadi dan keluarga, namun juga untuk pengembangan karir. Sejalan dengan yang dikemukakan oleh DeVito (1996) bahwa komunikator yang efektif memiliki kepercayaan diri sosial, sehingga perasaan cemas tidak dengan mudah dilihat oleh orang lain. Komunikator yang efektif akan selalu merasa nyaman bersama orang lain dan merasa nyaman berada dalam situasi komunikasi pada umumnya.

Pengetahuan dan keterampilan dalam berkomunikasi diperoleh melalui pelatihan. Pemahaman dan motivasi tentang menumbuhkan rasa percaya diri dalam membangun hubungan dengan orang lain, serta keterampilan dalam menggunakan kata-kata yang tepat dan mengatur bahasa tubuh ketika berbicara diberikan saat pelatihan. Subjek yang bertindak sebagai kelompok kontrol, secara keseluruhan tidak mengalami penurunan tingkat shyness. Hal tersebut dikarenakan kelompok kontrol tidak mendapatkan pelatihan. Sejalan dengan teori yang dikemukakan oleh Crozier (2000) bahwa individu yang mengalami shyness sering menghindari pertemuanpertemuan sosial sehingga memiliki kontak sosial yang sedikit. Penyebabnya yaitu kurangnya dukungan sosial, terjadi penolakan sosial atau diabaikan, dan kondisi lingkungan sekitar yang tidak mendukung. Adapun faktor-faktor dari dalam diri individu tersebut seperti merasa kurang percaya diri, cemas terhadap evaluasi sosial, dan takut membuat kesan yang tidak diinginkan.

Penelitian ini masih memiliki kekurangan dalam berbagai hal. Salah satunya yaitu pelatihan yang dirancang hanya sebatas melihat perubahan sikap pada subjek yang bertindak sebagai kelompok eksperimen. Menurut Kirkpatrick dan Kirkpatrick (2006) mengemukakan bahwa pelatihan yang dirancang untuk melihat perubahan perilaku dan hasil yang merupakan level 3 dan 4 dalam tahap evaluasi lebih efektif untuk melihat penurunan shyness. Di dalam penelitian ini juga peneliti tidak membedakan shyness yang ditinjau dari jenis kelamin, sedangkan ada penelitian yang dilakukan oleh Hermann dan Betz (2004) yang membedakan antara shyness yang dialami oleh laki-laki dan perempuan.

Saran dari peneliti adalah 1) Bagi subjek penelitian diharapkan mampu mengaplikasikan pengetahuan yang diperoleh dalam pelatihan serta mengembangkan keterampilan-keterampilan dalam mengatasi shyness yang berlebihan ketika berinteraksi dengan orang lain. 2) Mahasiswa pendatang diharapkan memiliki pengetahuan dan keterampilan sosial seperti keterampilan dalam berkomunikasi baik verbal maupun nonverbal, menanamkan konsep diri positif dalam diri, serta berpikir positif. 3) Bagi Universitas diharapkan selalu memberikan pengetahuan dan keterampilan sosial kepada mahasiswa baru sedini mungkin untuk meminimalisir 
masalah-masalah penyesuaian diri mahasiswa baru terutama mahasiswa pendatang. 4) Bagi peneliti selanjutnya diharapkan menyempurnakan penelitian ini dengan memperhatikan waktu dan kondisi ruangan untuk kenyamanan peserta pelatihan, merancang modul pelatihan sesuai dengan tujuan yang berfokus untuk mengurangi shyness, dan waktu untuk pelatihan diperpanjang atau lebih dari satu hari, serta mengontrol variabel-variabel lain seperti dukungan sosial, motivasi berprestasi, dan berpikir positif yang tidak dikontrol dalam penelitian ini.

\section{REFERENSI}

Anggarsari, N. H., \& Kumolohadi, R. 2007. Efektivitas Pelatihan Komunikasi Interpersonal untuk Mengurangi Rasa Malu (Shyness). Naskah Publikasi. Program Studi Psikologi Fakultas Psikologi dan Ilmu Sosial Budaya Universitas Islam Indonesia Yogyakarta. (Online). (http://psychology.uii.ac.id/images/stories/jadwal_kuliah/naskah-publikasi02320028.pdf, diakses 20 Maret 2011).

Azenismail. 2010. Manusia sebagai Makhluk Individu dan Makhluk Sosial. (Online). (http://azenismail.wordpress.com/2010/05/14/manusia-sebagai-makhlukindividu-dan-makhluk-sosial/, diakses pada tanggal 28 Juli 2011).

Azwar, S. 2010. Penyusunan Skala PSikologi. Yogyakarta: Pustaka Pelajar.

BAŞ, G. 2010. An Investigation of the Relationship Between Shyness and Loneliness Levels of Elementary Students in a Turkish Sample.International Online Journal of Educational Sciences. Vol. 2 (2): 419-440. (Online). (http://www.iojes.net/userfiles/Article/IOJES_211.pdf, diakses pada tanggal 12 April 2011).

Chaplin, J. P. 2006. Kamus Lengkap Psikologi. Jakarta: PT. RajaGrafindo Persada.

Crozier, W. R. 2000. Shyness Development, Consolidation and Change. London and New York: Routledge Progress in psychology.

Gerungan,W. A. 2004. Psikologi Sosial, Edisi Ketiga. Bandung: PT Refika Aditama. Gunawati, R., Hartati, S., \& Listiara, A. 2006. Hubungan antara Efektivitas Komunikasi Mahasiswa-Dosen Pembimbing Utama Skripsi dengan Stres dalam Menyusun Skripsi pada Mahasiswa Program Studi Psikologi Fakultas Kedokteran Universitas Diponegoro. Jurnal Psikologi Universitas Diponegoro. Vol. 3(2): 93-115. (http://ejournal.undip.ac.id/index.php/psikologi/article/download/659/533, diakses pada tanggal 27 April 2011).

Hatta, M. F. 2011. Pelatihan Manajemen Stres untuk Mengurangi Stres Kerja Karyawan Pelaksana Air Traffic Control (ATC) Makassar. Skripsi (tidak diterbitkan). Makassar: Universitas Negeri Makassar.

Henderson, L. M. \& Zimbardo, P. G. tanpa tahun. Shyness. Encyclopedia of Mental Health. (Online). (http://www.shyness.com/encyclopedia.html, diakses pada tanggal 17 April 2011).

Henderson, L. M., Zimbardo, P. G., dan Carducci, B. J. 1999. Shyness. An Article for the Encyclopedia of Psichology. (Online). (http://www.shyness.com/documents/1999/SHYENC599.pdf, diakses pada tanggal 27 April 2011). 
Hermann, K. S., \& Betz, N. E. 2004. Path Models of the Relationships of Instrumentality and Expressiveness to Social Self-Efficacy, Shyness, and Depressive Symptoms. Sex Roles. Vol. 51: 55-66.

Kirkpatrick, D. L., \& Kirkpatrick, J. D. 2006. Evaluating Training Programs, The Four Levels. Third Edition. San Francisco: Berrett-Koehler Publishers, Inc.

Lei, J. L. 2003. (Un)Necessary Toughness?: Those "Loud Black Girls" and Those "Quiet Asian Boys". Antropology and Education Quaterly. Vol. 34(2): 158-181. (Online). (http://www.twotowns.org/Lei.pdf, diakses pada tanggal 28 Juli 2011).

Mangkuprawira, S. T. 2008. Rasa Malu. (Online). (http://ronawajah.wordpress.com/2008/02/25/rasa-malu/, diakses pada tanggal 27 April 2011).

Manurung, H. 2008. Hubungan antara Motivasi Persahabatan dan Kesepian Mahasiswa Pendatang Universitas Negeri Makassar. Skripsi (tidak diterbitkan). Makassar: Universitas Negeri Makassar.

Maswan, S. 2001. Malu (Shyness). Bukit Mertajam Pulau Pinang: The Shyness Clinic. (Online). (http://www.sajadstudio.info/articale/malu2.pdf, diakses pada tanggal 20 Mei 2011).

Mohammed, A. R. \& Hamzah, M. D. 2005. Kajian Korelasi Emosi Malu dengan Pencapaian Akademik di Kalangan Mahasiswa Melayu. Jurnal Pendidik dan Pendidikan. Jil. 20: 153-167. (http://web.usm.my/education/publication/JPPrashid\%20(153-167)B.pdf, diakses pada tanggal 28 Juli 2011).

Myers, B. C. 2005. An Inhibition from Being Shy: Shyness and its Effects on Career Preferences of College Students. American Journal of Psychological Research. Vol. 1(1): 60-70.

Nufandi, R. 2000. Mengatasi Rasa Malu. Gresik: Putra Pelajar.

Priyatno, D. 2008. Mandiri Belajar SPSS. Yogyakarta: MediaKom.

Ridfah, A., Daud, M. \& Murdiana, S. 2007. Shyness pada Mahasiswa di Makassar. Jurnal Ilmu Psikologi Vol. 1 No. 2 Hal. 25-41. Makassar: Fakultas Universitas Negeri Makassar.

Ridfah, A. 2012. Intervensi Cognitive Behavior Therapy (CBT) untuk Menurunkan Derajat Shyness pada Mahasiswa Fakultas X Universitas Y di Kota Makassar. Tesis (tidak diterbitkan). Bandung: Magister Psikologi Profesi Fakultas Psikologi Universitas Padjadjaran.

Shadish, W. R., Cook, T. D., \& Campbell, D. T. (2002). Experimental and quasiexperimental design. New York: Houghton Mifflin.

Sears, D. O., Freedman, J. L., \& Peplau, L. A. 1999. Psikologi Sosial. Jilid 1 Edisi Kelima. Jakarta: Erlangga.

Seniati, L., Yulianto, A., \& Setiadi, B. N. 2009. Psikologi Eksperimen. Jakarta: Indeks.

Senjaya, S. 2010. Pengertian Mahasiswa. (Online), (http://sutisna.com/artikel/artikelkesehatan/pengertian-mahasiswa/, diakses pada tanggal 28 Juli 2011).

Sugiyono. 2011. Statistika untuk Penelitian. Bandung: CV Alfabeta.

Supratiknya, A. 1995. Komunikasi Antar Pribadi: Tinjauan Psikologi. Yogyakarta: Kanisius. 
Tubbs, S. L., \& Moss, S. tanpa tahun. Diterjemahkan oleh Mulyana, D., \& Gembirasari. 2005. Human Communication; Prinsip-Prinsip Dasar. Bandung: PT Remaja Rosdakarya.

Xu, Y., Farver, J. A. M., Yang, Y., \& Zeng, Q. 2008. Chinese Children's Conceptions of Shyness. Merrill-Palmer Quarterly. Vol. (54)4: 515-544. (Online). (http://www.yu-yang.com/papers/Xu_Farver_Yang_Zeng_2008_MPQ.pdf, diakses pada tanggal 16 April 2011). 